\title{
APPLICATION OF SOLUTIONS-FOCUSED COUNSELING (SFC) TO IMPROVE STUDENT MOTIVATION: AN SINGLE SUBJECT RESEARCH
}

\author{
Lintang Setiono', Marjohan², Marlina ${ }^{3}$ \\ 1 Universitas Negeri Padang, Indonesia, lintangsetiono@gmail.com \\ 2 Universitas Negeri Padang, Indonesia, marjohan@konselor.org \\ ${ }^{3}$ Universitas Negeri Padang, Indonesia, marlina.muluk@gmail.com
}

\begin{abstract}
This study aims to examine the effectiveness of solution-focused counseling to improve student learning motivation. The research method used is Single Subject Research with A-B-A design. The subject of this study was the eighth-grade students of SMP 13 Padang. Five children who had very low learning motivation as subjects of SFC intervention. Data collection instruments of this research are learning motivation scale, interview, and observation. Data analysis techniques are used with visual analysis of data and graphics. The findings of this study indicate that counseling focuses on effective solutions to improve student learning motivation on the subject of $A F, A B, G L, A G, R Z$, as a result of changes in counseling. Furthermore, SFC is also effective in increasing student motivation in the baseline phase to increase during an intervention. In addition, the target subject was active during the counseling process and satisfied with the SFC intervention provided by the counselor. Based on the research findings it is suggested that counselors apply SFC in counseling both individuals and groups. Research findings provide a theoretical contribution to SFC which is applied in improving learning motivation.
\end{abstract}

Keywords: solution-focused counseling, motivation learning, single subject research

This is an open access article distributed under the Creative Commons 4.0 Attribution License, This license lets others remix, tweak, and build upon your work even for commercial purposes, as long as they credit you and license their new creations under the identical terms $\odot 2018$ by author and Universitas Negeri Padang.

\section{INTRODUCTION}

Motivation is an absolute requirement in learning, students who learn without or lack motivation will not succeed maximally. Motivation is very important in learning activities because with motivation to encourage the spirit of learning and conversely, lack of motivation will weaken the spirit of learning (Budiono, Degeng, \& Ardhana, 2016; Rehman \& Haider, 2013; Sardiman, 2012). Learning motivation is an energize, direct, and persevering behavior that drives selfmotivation to try to fulfill the overall needs of learning (sustain behavior)(Santrock, 2011). (Ormrod, 2014) Further stated that motivation increases perseverance in learning at school.

The description above can be interpreted that learning motivation is the overall driving force in students that lead to learning activities, which ensures the continuity of learning activities so that the activities desired by the students are achieved. The aspects examined in this study are: diligent in doing the tasks, resilient in solving problems and obstacles independently, having the urge to learn, and showing interest in learning(McClelland, 1987; Neviyarni \& Irianto, 2016; Sardiman, 2012). Students who have low learning motivation will bring negative behavior to themselves. The behaviors that appear are like; ditching, lazy learning, doing assignments, no desire to know, not caring about its value, not eager to learn in class, getting bad grades, etc. (Neviyarni \& Irianto, 2016; Nuzliah, 2015; Sardiman, 2012)

Based on the results of interviews with subject teachers in SMP Negeri 13 Padang, it was revealed that many VIII graders had low learning motivation. This can be seen from students often leaving the classroom when learning, students often sleep in class, students pull out of class, 
students are ignorant of their achievement, and many students do not do the assignments given by the teacher.

Furthermore, the results of interviews with BK N 13 Padang teachers have obtained data that the handling of low student learning motivation had been less than optimal because every week there was only 1 hour of BK study in each class. BK teachers feel that the services provided are not optimal, due to the limited time and interest of students to follow the service. In addition, the services provided are informative about new things, and emphasize the discussion of the problem (problem-talk) and the background of the problem (history), so that the session used becomes more and longer.

Handling problems from low student motivation, so far are still basically dominated only by giving training and problem-talk alone (Wiyono, 2013). One of the weaknesses of training is determining the ultimate goal in the hands of the counselor when in fact every student has the ability to be able to measure the success achieved (Corey, 2009; Neukrug, 2012; Seligman, 2006). In addition, limited time in the school environment is also considered less effective, where counselors must deal with various problems that exist in the school environment and spend a lot of time. In this regard, the counselor must look for a more effective and efficient approach to counseling.

(Soedjito Taathadi, 2014) states that the SFC model is suitable for schools because this approach focuses on students' strengths and abilities rather than their weaknesses. The focus of the SFC approach is future-oriented and solutions rather than looking for problems that cause problems. SFC is more efficient and realistic to do in school settings than other approaches. The results of the study by (Trepper, T. S., Dolan, Y., McCollum, E. E., \& Nelson, 2006) show that SFC is effective in elementary, middle school and college students.

De Jong \& Berg said "Solution-focused therapists view clients as wanting to change, and therapists do their best to help bring about change" (Shaff, 2012). The description above can be interpreted that the SFC approach focuses on what the client wants, and the role of the counselor helps to realize what the client wants. The implementation of SFC focuses more on the solutiontalk and the ultimate goal of the counseling process is in the hands of clients who have the ability to solve their own problems(Bannink, 2007; Iveson, 2002; Sumarwiyah, Zamroni, \& Hidayati, 2015).

Based on the overall study described, the researcher assumes that the SFC approach is effectively used in school settings. This is also one reason researchers are intrigued to test the effectiveness of the use of the SFC approach in school settings, especially to improve student learning motivation.

\section{METODH}

This research uses experimental research design with single subject designs. This design is designed to study human behavior individually intensively, does not mean that the subject is only 1 (one) person, usually between 3 (three) to 5 (five) people, even though only 1 (one) person (Sugiyanto, 1995). The design chosen in this study is the A-B-A Baseline (A) -Intervention (B) Follow up (A') model (Barlow, D. H \& Hersen, n.d.). A is an embodiment of the baseline condition, $\mathrm{B}$ is a manifestation of conditions after getting intervention or treatment, and $\mathrm{A}$ 'is a condition after treatment or intervention is eliminated. A's 'follow-up phase' is a control phase to find out changes so that conclusions can be drawn as to whether solution-focused counseling can improve student learning motivation. 
The subjects of this study were eighth-grade students using purposive sampling technique. Before the implementation of this research was carried out, it was given a learning motivation scale to capture potential research subjects. Based on the scale of learning motivation, there were 8 students who became prospective subjects in the very low category. Furthermore, interviews were conducted with teachers and observations were made to students to establish the subject members. Based on the results of interviews and observations, there were 5 subjects, 3 children had to be aborted based on the teacher's recommendations and the observations of the researchers.

The instrument in this study is, the treatment material instrument that contains SFC treatment procedures and data collection instruments namely observation and interview guidelines. Whereas Target Behavior and Measurement of Behavioral Behavior are learning motivation: (1) Diligent in learning and facing assignments, (2) Resilient in facing learning difficulties, (3) Having encouragement/desire to learn, (4) Showing interest in learning. Measurement of behavioral targets using observation sheets and interviews filled in by the authors, class teachers during the baseline phase, intervention and follow-up.

\section{RESULT AND DISCUSSION}

Measurements were made using two (2) data collection tools namely observation and interviews in order to get a representation of student learning motivation conducted in the baseline (A), intervention (B), and follow-up (A ') phases. The following measurement results for each session of the five students will be shown in the following table.

Table 1. Results of Measurement for Each Session

\begin{tabular}{|c|c|c|c|c|c|c|c|c|c|c|c|c|c|}
\hline \multirow[b]{2}{*}{ Students } & \multicolumn{4}{|c|}{ Fase Baseline (A) } & \multicolumn{5}{|c|}{ Fase Intervensi (B) } & \multicolumn{4}{|c|}{ Fase Follow Up (A') } \\
\hline & $\begin{array}{c}\text { Sesi } \\
1\end{array}$ & $\begin{array}{c}\text { Sesi } \\
2\end{array}$ & $\begin{array}{c}\text { Sesi } \\
\mathbf{3}\end{array}$ & $\begin{array}{c}\text { Sesi } \\
\mathbf{4}\end{array}$ & $\begin{array}{c}\text { Sesi } \\
1\end{array}$ & $\begin{array}{c}\text { Sesi } \\
2\end{array}$ & $\begin{array}{c}\text { Sesi } \\
\mathbf{3}\end{array}$ & $\begin{array}{c}\text { Sesi } \\
\mathbf{4}\end{array}$ & $\begin{array}{c}\text { Sesi } \\
5\end{array}$ & $\begin{array}{c}\text { Sesi } \\
1\end{array}$ & $\begin{array}{c}\text { Sesi } \\
2\end{array}$ & $\begin{array}{c}\text { Sesi } \\
\mathbf{3}\end{array}$ & $\begin{array}{c}\text { Sesi } \\
\mathbf{4}\end{array}$ \\
\hline $\mathrm{AF}$ & 16 & 15 & 16 & 15 & 19 & 23 & 28 & 32 & 36 & 34 & 35 & 35 & 36 \\
\hline $\mathrm{AB}$ & 15 & 16 & 16 & 16 & 18 & 21 & 29 & 32 & 37 & 38 & 37 & 39 & 38 \\
\hline GL & 16 & 15 & 16 & 15 & 18 & 23 & 28 & 31 & 35 & 37 & 38 & 38 & 37 \\
\hline $\mathrm{AG}$ & 16 & 15 & 16 & 15 & 17 & 22 & 29 & 34 & 36 & 36 & 36 & 35 & 36 \\
\hline $\mathrm{RZ}$ & 15 & 16 & 16 & 16 & 18 & 23 & 27 & 32 & 33 & 35 & 33 & 33 & 34 \\
\hline
\end{tabular}

1. $\mathbf{A F}$

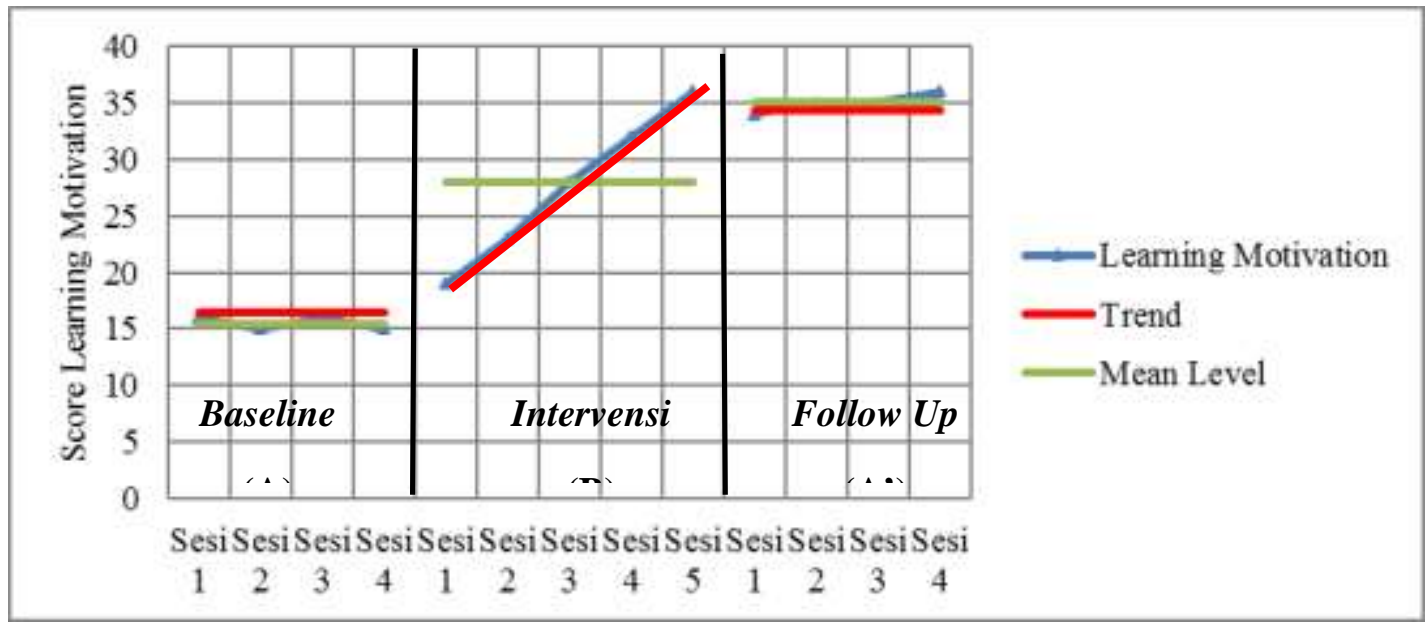

Graph 1. Frequency of AF Learning Motivation in Baseline, Intervention and Follow-Up Phases 
Based on the graph above, shows the change in the frequency of AF learning motivation in the baseline phase obtained by the stability range score of 2.4 , the mean level of 15.5 , the upper limit of 17.9, and the lower limit of 13.1. While the Stability Trends are in the stable category of $100 \%$. Besides that, based on the interview that the researcher did to the BK teacher, it was concluded that AF showed less serious behavior in learning. AF is lazy to make assignments given by the teacher, $\mathrm{AF}$ feels cooler playing with his peers than learning. This condition is reinforced by truant behavior due to not making assignments. AF also often appears sleepy / sleeping in class when the lesson takes place.

Furthermore, AF was given SFC intervention and obtained a stability range score of 5.4, mean level 27.6, an upper limit of 33, lower limit of 22.2, with a tendency to the stability of $80 \%$. Based on these data it can be concluded that students' learning motivation has increased in the SFC intervention phase of 36-19 $=17$. Besides that, $\mathrm{AF}$ shows changing behavior from the baseline phase where AF began to appear serious in making the assignments given by the teacher, seemed enthusiastic about the material is given by the teacher, and showed great interest in the material.

After the intervention is complete, follow-up is given to see the AF condition after the intervention. Achievement of the stability range score of 5.4, mean level 35, an upper limit of 40.4, a lower limit of 29.6. In this follow-up phase, it appears to be stable in the AF condition with the acquisition of a stability tendency score of $100 \%$. It can be concluded that there is no change in $\mathrm{AF}$ conditions after intervention and remains in high criteria.

2. $\mathbf{A B}$

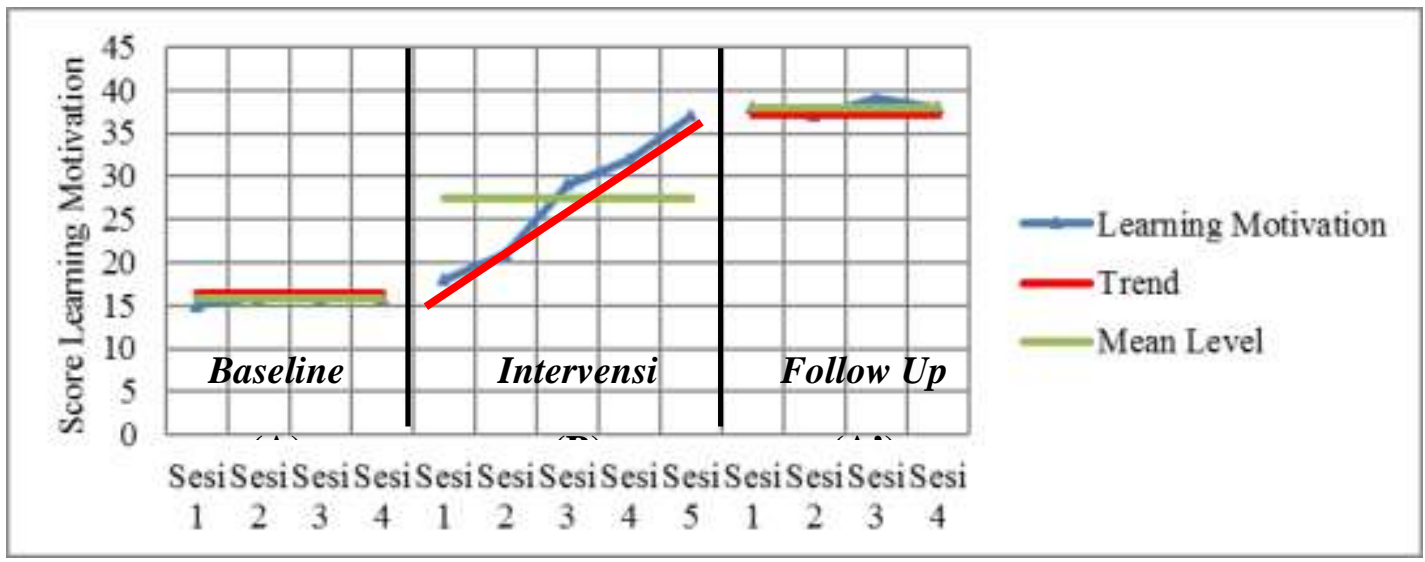

\section{Graph 2. Frequency of $A B$ Learning Motivation in Baseline, Intervention and Follow-Up} Phases

Based on the baseline phase, the stability range score was 2.4 , the mean level was 15.75 , the upper limit was 18.17 and the lower limit was 13.35. While the Stability Trends are in the stable category of $100 \%$. In addition, based on the results of the interview, it was revealed that $\mathrm{AB}$ often pulled out of class and often had permission to go out to the bathroom. $\mathrm{AB}$ also felt very lazy to learn, $\mathrm{AB}$ also felt bored with the classroom environment or the lessons given by the teacher. it can be concluded that encouragement and interest in learning $A B$ are very lacking.

Furthermore, $\mathrm{AB}$ was given SFC intervention and obtained a score of intervention stability range of 5.55, a level means of 27.4, an upper limit of 32.95 , a lower limit of 21.85 , with a tendency to the stability of $40 \%$. Based on these data it can be concluded that student learning motivation has increased in the SFC intervention phase of 37-18 $=19$. Besides, that $\mathrm{AB}$ shows 
behavior that changes from the baseline phase in which $\mathrm{AB}$ is committed to increase motivation to learn by means of seriousness in learning. To overcome laziness in the classroom, $\mathrm{AB}$ will make a unique and interesting note, so $\mathrm{AB}$ does not get bored quickly. $\mathrm{AB}$ will also propose to teachers to study in other places such as prayer rooms, parks, and other places that support so that learning is fun.

Follow-up was given to see AB's condition after the intervention. The follow-up outcome score in the stability range was 5.85 , the mean level was 38 , the upper limit was 43.85 , the lower limit was 32.15. In this follow-up phase, it seems to stabilize the AB condition with the acquisition of a stability tendency score of $100 \%$. It can be concluded that there is no change in the condition of $\mathrm{AB}$ after the intervention and remains in the high criteria.

3. GL

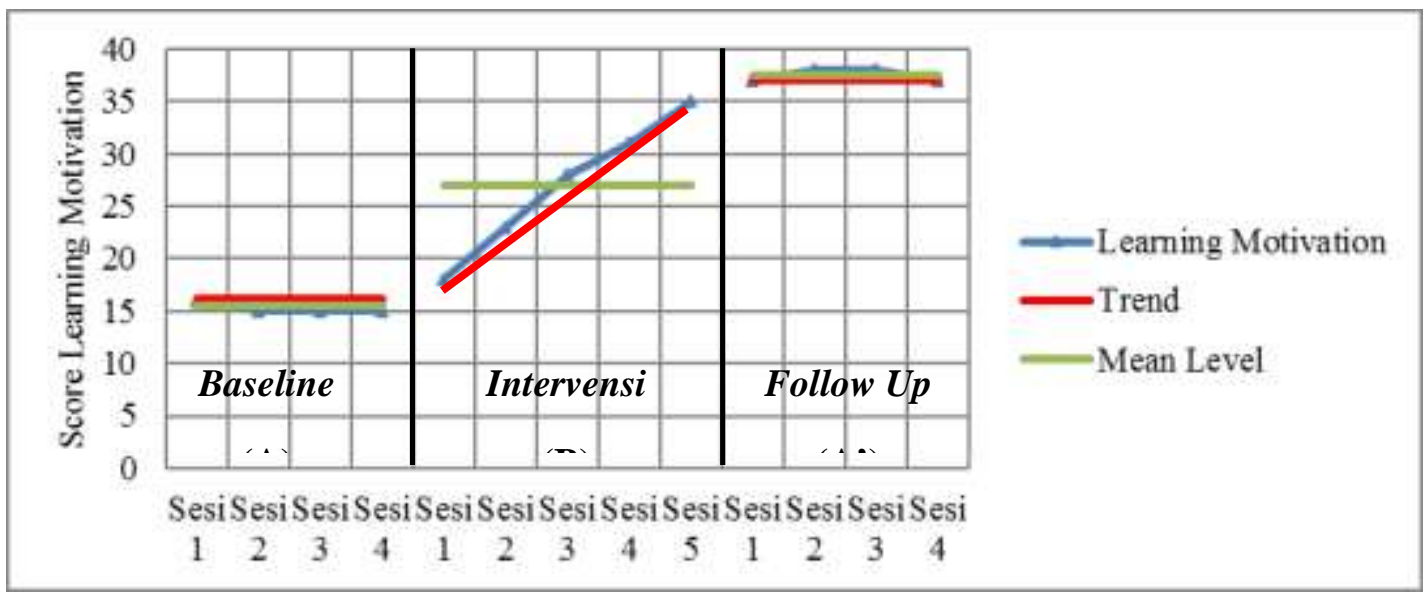

\section{Graph 3. Frequency of GL Learning Motivation in Baseline, Intervention and Follow-Up Phases}

Based on the baseline, the range of stability scores on the baseline is 2.4 , mean level 15.5, an upper limit of 17.9 and lower limit of 13.1. While the tendency of stability is in the stable category of $100 \%$. In addition to that, the results of interviews with BK teachers revealed that GL often seemed desperate in learning, previous counselors had counseled with GL, it was revealed that GL was not interested in learning, even though according to learning GL it was important. That is what causes GL to not have enthusiasm in learning if getting a GL school assignment often does not make and reason behind. GL also rarely makes lesson notes, if the teacher gives GL the opportunity to move forward to work on the problem, GL often answers it can't. Based on the interview results above, it can be concluded that GL has a low learning motivation.

Furthermore, SFC intervention was performed and obtained a score of intervention stability range of 5.25 , mean level 27 , an upper limit of 32.25 , a lower limit of 21.75 , with a tendency for the stability of $20 \%$. Based on these data it can be concluded that student learning motivation has increased in the SFC intervention phase of 35-18 $=17$. Based on interviews with GL revealed that GL will be serious in learning that is by working on the questions given by the teacher. No matter how difficult the questions given by GL will try to work, if GL doesn't understand then GL will ask friends or teachers. GL will also try to find material that has not been understood by creating study groups, according to effective learning GL, namely with the help of friends in groups. 
After the intervention is complete, follow-up is given to see the GL condition after an intervention. Follow-up results were respectively $37,38,38,37$ with a stability range of 5.7, mean level 37.5, an upper limit of 43.2, a lower limit of 31.8. In the follow-up phase, it appears to the stability of GL conditions with the acquisition of a stability tendency score of $100 \%$. It can be concluded that there is no change in GL condition after intervention and remains in high criteria.

4. AG

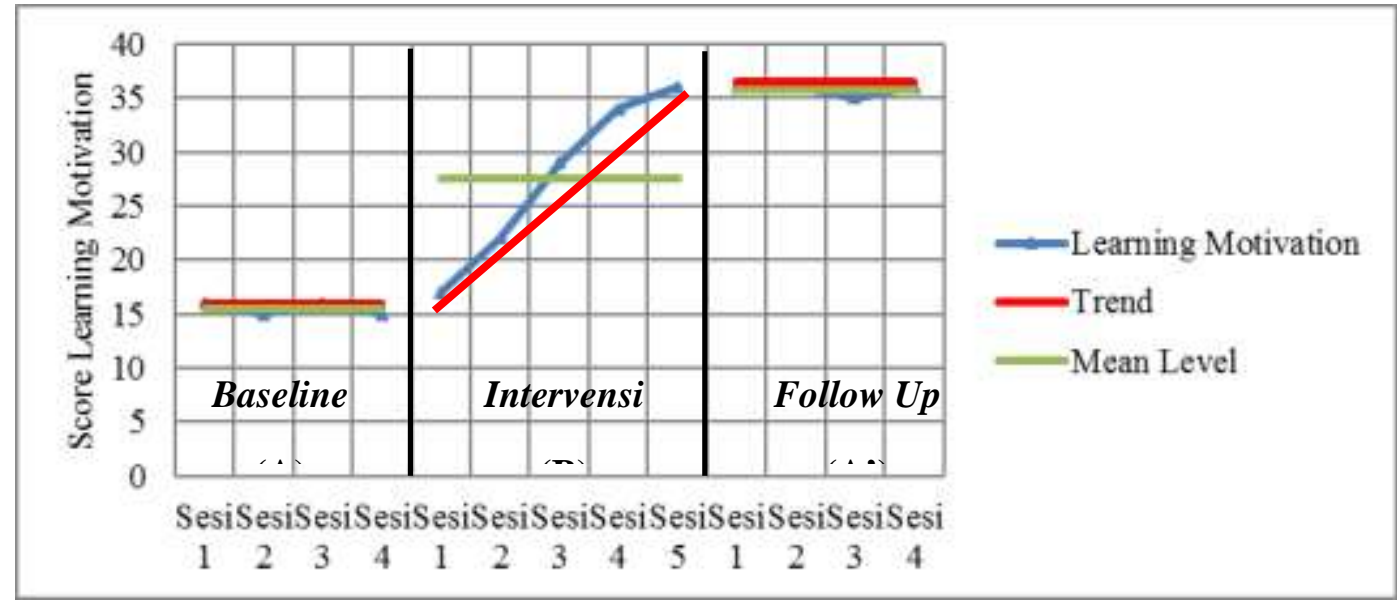

\section{Graph 4. Frequency of AG Learning Motivation in Baseline, Intervention and Follow-Up Phases}

In the Baseline AG phase, the stability range score was 2.4 , the mean level was 15.5 , the upper limit was 17.9 and the lower limit was 13.1. While the Stability Trends are in the stable category of $100 \%$. The results of the interview with the BK teacher revealed that AG was a quiet student in the class, $A G$ also rarely even gave opinions during discussions, friends $A G$ often complained if one group with AG. Based on an interview with AG it was revealed that AG did not have a school interest, but parents wanted to go to school. AG wants more for business. Therefore, AG is lazy to learn, so AG goes to school without sincere intentions from within.

Subsequently, SFC interventions were performed and obtained a score of 5.4 stability interventions, level mean 27.6, upper limit 33, lower limit 22.2, with a tendency for the stability of $20 \%$. Based on these data it can be concluded that student learning motivation has increased in the SFC intervention phase of 36-17 $=19$. In addition, after the intervention, an interview with AG was carried out and obtained results that AG would be more enthusiastic in learning, AG realized that he was quiet, but AG was committed to being active in class, especially when discussing with friends. AG's enthusiasm for schooling will be further enhanced, because AG realizes that the goal of trading requires knowledge and skills in communication, it can be trained by learning both science and communication interactions in schools.

After the intervention is complete, follow-up is given to see $A G^{\prime}$ 's condition after the intervention. The results of the stability range were 5.4, the mean level was 35.75 , the upper limit was 41.15 , the lower limit was 30.35 . In this follow-up phase, it appears to the stability of the AG condition with the acquisition of a stability tendency score of $100 \%$. It can be concluded that there is no change in AG condition after intervention and remains in high criteria. 
5. RZ

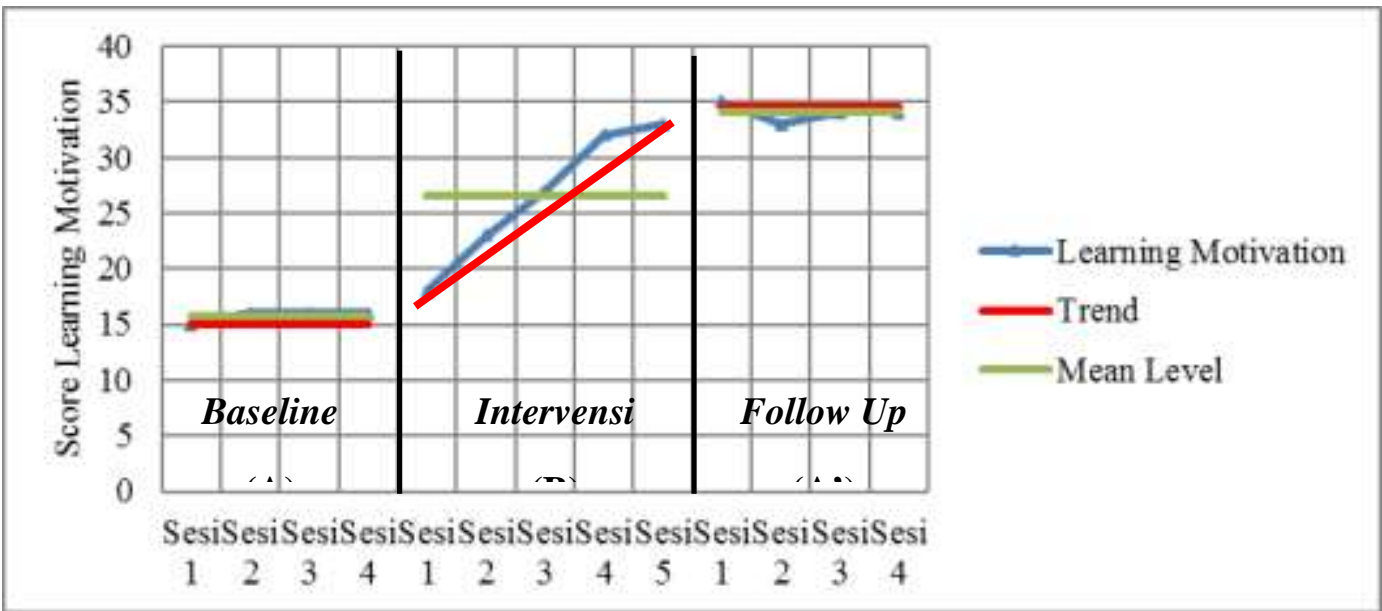

\section{Graph 5. Frequency of RZ Learning Motivation in Baseline, Intervention and Follow-Up Phases}

Based on the baseline results obtained the results that RZ obtained a stability range score of 2.4, the mean level of 15.75, the upper limit of 18.15, and the lower limit of 13.35 . While the Stability Trends are in the stable category of $100 \%$. The results of interviews with teachers revealed that students were indifferent to their learning outcomes/achievements, it appeared in the daily process of learning RZ. Just as RZ often cheats on exams, often leaving class, they are not interested in getting new material, indicated by frequent sleep during lessons. The results of interviews with $\mathrm{RZ}$ also revealed that he felt lazy with learning, according to RZ learning was boring, RZ also conveyed many successful people without learning. So it can be concluded that RZ feels less interested in learning and there is no interest in learning.

Furthermore, the RZ was given interventions 1, 2, 3, 4, SFC and obtained scores of 18, 23, $27,32,33$, with a range of intervention stability of 4.95, mean level 26.6, upper limit of 31.55, lower limit of 21.65 , with a tendency to stability of $40 \%$. Based on these data it can be concluded that student learning motivation has increased in the SFC intervention phase of 33$18=15$. In addition, the results of interviews with RZ revealed that RZ would be enthusiastic in learning because $\mathrm{RZ}$ realized that learning achievement must be realized by having high learning motivation. The problem of RZ who often cheats on exams often leaves the classroom and other problems that will be corrected by RZ by means of enthusiasm in learning. RZ also realizes that the success of others who are in school and who are not in school are different.

After the intervention was completed, a follow-up was given to see the post-intervention RZ condition with a stability range of 5.25, mean level 34, an upper limit of 39.25 , a lower limit of 28.75. In the follow-up phase, it appears to the stability of the RZ condition with the acquisition of a stability tendency score of $100 \%$. It can be concluded that there is no change in $\mathrm{RZ}$ conditions after the intervention and remains in the medium criteria. 


\section{Group Analysis}

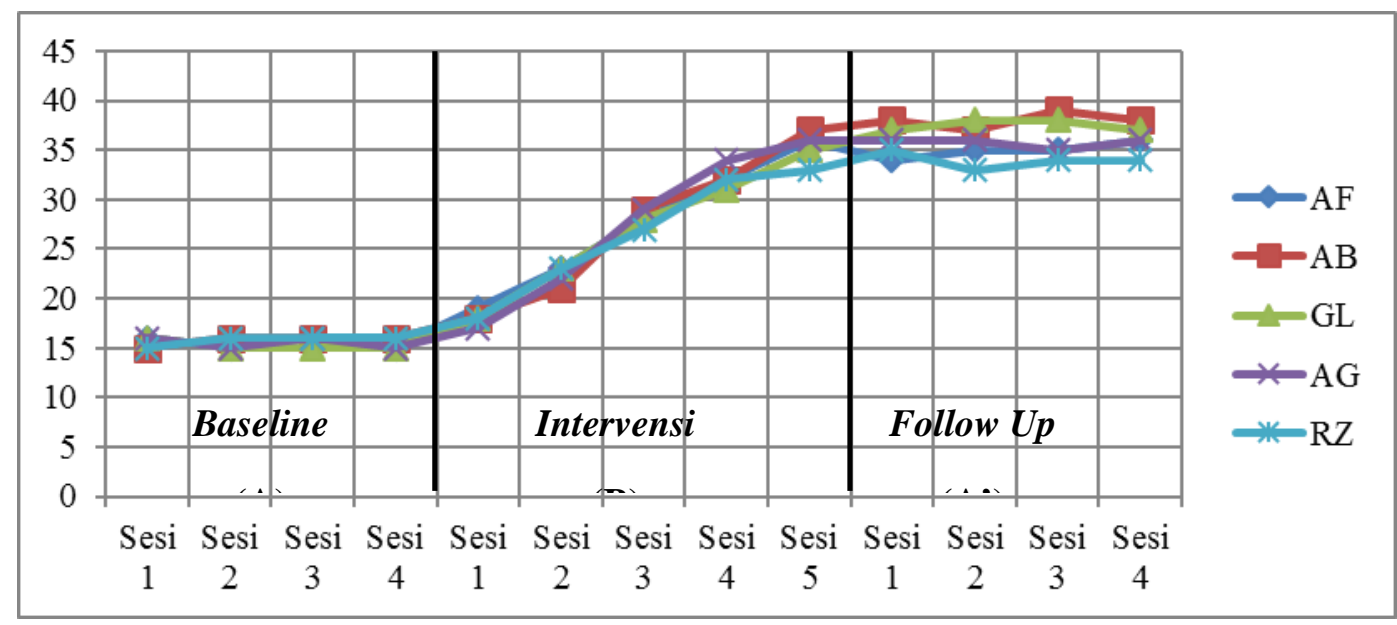

\section{Graph 6. Frequency Learning Motivation in Group in Baseline, Intervention and Follow- Up Phases}

Group analysis will explain the results of the dynamics of the development of the subject of the intervention (Client) thoroughly. This analysis explains the development of the dynamics of increasing student learning motivation by providing solution-focused counseling interventions. The score obtained is the measurement results with the help of data collection tools namely, observation guidelines and interview guidelines. Trends, levels, and variability show students' learning motivation increases with the provision of solution-focused counseling

\section{CONCLUSION}

Based on the analysis that has been carried out namely the analysis of conditions and analysis between conditions, visual graphics vision obtained the conclusion that counseling focuses on effective solutions to increase student motivation. This is based on the criteria it says the effectiveness of counseling focuses on solutions to increase student motivation that is marked by an increase in scores from low to high results from the accumulation of observation and interviews, data overlap between the baseline phase and the follow-up phase of $0 \%$, and the occurrence of a positive trend line. Positive trends can be seen from the traces of data obtained in the intervention phase, showing a gradual increase in the level of student motivation scores. began to be seen from the first session of intervention until the last session of intervention. The stability and effect tendencies were stable in the intervention phase for each student with a score above $85 \%$. With the occurrence of positive trends, it is predicted that there will be a gradual increase in student learning motivation.

The findings from this research process at the baseline stage (A) did not have a significant difference in scores even though the average score between the groups had differences. This is regardless of the validity that affects the subject in the study. The description is supported by Hepner, P.P., Wampold, B.E., \& Kivlinghan, (2008) explaining that validity can be interpreted as the level of accuracy/ validity of a study. Validity that is likely to have an influence on the condition of the subject of this study includes internal validity and external validity.

Internal validity assumed to affect the subject of this research are: history, past events experienced by the subject, Cambell \& Stanley (in Ross \& Morrison, 2004; Marlina, 2015), maturity, the occurrence of changes both biologically and non-biologically that can affect the 
subject (Kazdin, 2003; Marlina, 2014), procedures, the occurrence of boredom affecting test results (Rosnow, \& Rosenthal, 2005).

Furthermore, some assumptions of external validity that influence the subject of the study, among others: reactive settings, refers to the emergence of something new from the subject such as decreased interest, learning motivation or fatigue (Kazdin, 2003), in addition multiple treatments become a threat to validity This external refers to a research situation where (1) the sample is given more than one experimental intervention (or independent variable) in the same study or (2) the same individual participates in more than one study (Pedhazur \& Schmelkin, 2013; Marlina, 2017).

In the Intervention phase (B) shows an increase in student motivation before and after the SFC treatment. Based on the results of the study in outline shown by changes in student motivation in individuals and groups in the baseline phase (A) and follow-up (A ') SFC intervention. Supporting the description of the research results, (Fanaei, Gorji, \& Abedi, 2014) in his research report revealed that SFC is effective in increasing internal and external learning motivation in students in Iran, then (Ermawati, 2010) the results of her research also say that therapy focuses on solutions to increase learning motivation in class X high school students. Concept support from previous researchers who examined students' motivation to strengthen the results of this study. But in this research process, researchers use or combine solutionfocused counseling approaches. The results found that the application of counseling focuses on effective solutions to increase student motivation

Solution-focused counseling is an approach built on the potential of counselees who are actually able to construct solutions to the problem. KSF is a counseling approach which is influenced by postmodern thinking in counseling through two main activities, namely consciousness raising and making choices in alleviating problems. This SFC counseling is focused on improving the solution of each client's problems, focusing on solution-talk and directing on what steps the counselee will do later on with the problems inherent in his life so that the session becomes concise and concise.

In the solution-focused counseling application, the counselor must focus on the solution so that the counselee's problems are solved. In educational settings, sessions used are usually three to six sessions (Davis, \& Osborn, 2000; Lines, 2006) This is consistent with the results of the study of Littrel et al 1995 in the school student population, the number of counseling sessions was three times (Kelly, Wood, \& Mansell, 2013; MacDonald, 2007) Solution-focused counseling is not a quick fix, but counseling is designed to be limited to focusing on an intervention short-term session plan that aims not to completely cure but only to regulate the client on what is done (Davis \& Osborn in Lines, 2006)). This is in line with the purpose of counseling, namely "Service assistance by professionals to someone or a group of individuals to develop KES and the handling of KES-T with a focus on independent individuals who are able to control themselves" (Prayitno, 2017:85).

In addition, therapeutic change factors are basically summarized into four factors and have a percentage of contribution to changes in the counselee. (Bertolino, B \& O'Hanlon, 2002) The four factors are: (1) 40\% extra-therapeutic factors for improvement and change in the client, (2) relation factor $30 \%$, (3) 15\% expectation factor, (4) special technical factor $15 \%$ SFC. Thus it can be concluded that changes or problem-solving are more common in the client, not solely derived from approaches or counseling techniques. In other words, it can be 
concluded that humans basically have the ability and strength to solve the problems they experience so they can achieve prosperity in their lives.

\section{REFERENCES}

Bannink, F. P. (2007). Solution-focused brief therapy. Journal of Contemporary Psychotherapy, 37(2), 87-94. https://doi.org/10.1007/s10879-006-9040-y

Barlow, D. H \& Hersen, M. (n.d.). Single-Case Experimental Designs: Strategies For Studying Behavior Change Second Edition. In and social studies Pergamon Press, Pergamon international library of science, technology, engineering (Ed.), 1976. New York.

Bertolino, B \& O'Hanlon, B. (2002). Collaborative, Competency - Based; Counseling And Psychotherapy. Boston: Allyn and Bacon.

Budiono, I. A., Budiono, I. A., Degeng, I. N. S., \& Ardhana, W. (2016). The Effect of Mind Mapping Method And Learning Motivation on Writing Short Story Learning Skills In Indonesian Subject The Effect of Mind Mapping Method And Learning Motivation on Writing Short Story Learning Skills In Indonesian Subject, (March 2017). https://doi.org/10.9790/7388060501109112

Corey, G. (2009). Theory and Practice of Group Counseling, Eighth Edition. USA: Beimont, CA: Brooks/Cole, Cengage Learning.

Davis, T., \& Osborn, C. (2000). The solution- focused school counselor: Shaping professional practice. Philadelphia: PA: Taylor and Francis.

Ermawati, H. (2010). Terapi Berfokus Solusi Untuk Meningkatkan Motivasi Belajar Pada Siswa Kelas X Sma Negeri 1 Mojolaban Kecamatan Mojolaban Kabupaten Sukoharjo Tahun Pelajaran 2009/2010, [Bambang D.

Fanaei, Z., Gorji, Y., \& Abedi, M. R. (2014). The Effect of Solution-Focused Group Counseling on Internal Motivation of Students of Islamic Azad University of Khomeini Shahr 2012- 2014, 3, 207-211.

Hepner, P.P., Wampold, B.E., \& Kivlinghan, D. . (2008). Research Desain in Counseling. California: Thomson Brooks/Cole.

Iveson, C. (2002). Solution-focused brief therapy. Advances in Psychiatric Treatment, 8(2), 149156. https://doi.org/10.1192/apt.8.2.149

Kazdin, E. A. (2003). Research Design in Clinical Psychology, 4th Edition. Yale University: Pearson Education.

Kelly, R. E., Wood, A. M., \& Mansell, W. (2013). Flexible and tenacious goal pursuit lead to improving well-being in an aging population: A ten-year cohort study. International Psychogeriatrics, 25(1), 16-24. https://doi.org/10.1017/S1041610212001391

Lines, D. (2006). Brief Counseling In Schools: Working With Young People 2th Edition. London: Sage Publication.

MacDonald, A. (2007). Solution Focused Therapy; Theory, Research \& Practice. London: Sage Publication Inc. 
McClelland, D. C. (1987). Human Motivation. New York: Cambrigde Unversity Press.

Marlina, M. (2014). Kelompok Teman Sebaya, Popularitas, dan Preferensi Sosial Anak Berkesulitan Belajar di Sekolah Dasar Inklusif. Jurnal Penelitian dan Pengembangan Pendidikan Luar Biasa, 1(1), 8-14.

Marlina, M. (2017). Developing Peer-Mediated Social Skills Intervention Model for Children with Special Needs. In International Conference on Education (pp. 1031-1040).

Marlina, M. (2015). Asesmen Anak Berkebutuhan Khusus: Pendekatan Psikoedukasional Edisi Revisi.

Neukrug, E. (2012). The World of the Counselor An Introduction to the Counseling Profession.

Neviyarni, N., \& Irianto, A. (2016). Efektivitas Layanan Bimbingan Kelompok untuk Meningkatkan Motivasi Belajar dan Mengurangi Perilaku Membolos Siswa. Konselor, 3(4), 184-200.

Nuzliah. (2015). Kontribusi Motivasi Belajar, Kreativitas Terhadap Problem Solving (Pemecahan Masalah) Siswa Dalam Belajar Serta Implikasi Terhadap Bimbingan Dan Konseling Di Smpn 29 Padang. Jurnal Edukasi Vol, 1(2), 157-174.

Ormrod, J. E. (2014). Educational Psychology Developing Learners Eight Edition. USA: Pearson Education.

Pedhazur, E.J. \& Schmelkin, L. . (2013). Measurement, Design, and Analysis: An Integrated Approach. In Psychology Press (Ed.). Taylor \& Francis Group. New York London.

Prayitno. (2017). Konseling Profesional yang Berhasil. Depok: Rajagrafindo persada.

Rehman, A., \& Haider, K. (2013). The Impact of Motivation on Learning of Secondary School Students in karachi: An Analytical Study. Educational Research International, 2(2), 139-147.

Rosnow, R. L \& Rosenthal, R. (2005). Beginning Behavioral Research: A Conceptual Primer, 5th Edition. Pearson Education.

Ross, S. M., \& Morrison, G. R. (2004). Experimental research methods. Time, 2(January 2003), 1021-1044. Retrieved from http://aect.org/edtech/ed1/38.pdf

Santrock, J. W. (2011). Educational psychology 5 edition. Newyork: McGraw- Hill. E books.

Sardiman. (2012). Interaksi dan Motivasi belajar Mengajar. (PT Raja Grafindo Persada, Ed.). Jakarta.

Seligman, L. (2006). Theories of counseling and psychotherapy: Systems, strategies, and skills. (2nd ed.). Upper Saddle River: New Jersey: Pearson Education, Ltd.

Shaff. S, R. (2012). Theories of Psychotherapy and Counseling Concepts and Cases. (B. C. Learning, Ed.).

Soedjito Taathadi, M. (2014). Application of Solution-Focused Brief Therapy (SFBT) to Enhance High School Students Self-Esteem: An Embedded Experimental Design. International Journal of Psychological Studies, 6(3), 96-105. https://doi.org/10.5539/ijps.v6n3p96

Sugiyanto. (1995). Metodologi Penelitian. (U. Press, Ed.). Surakarta. 
Sumarwiyah, Zamroni, E., \& Hidayati, R. (2015). Solution Focused Brief Counseling (Sfbc): Alternatif Pendekatan Dalam Konseling Keluarga. Pentingnya Pemahaman Kedudukan Dan Fungsi Bahasa Indonesia Sebagai Pemersatu Negara Kesatuan Republik Indonesia, 1(2), 234242. https://doi.org/10.24176/jkg.v1i2.409

Trepper, T. S., Dolan, Y., McCollum, E. E., \& Nelson, T. (2006). Steve de Shazer and the future of solution-focused therapy. Journal of Marital and Family Therapy, 32 (2),133.

Wiyono, B. D. (2013). Keefektifan Konseling Kelompok Singkat Berfokus Solusi Untuk Meningkatkan Motivasi Berprestasi Siswa SMK. Universitas Negeri Malang. 